\title{
Taxation features in the context of economic sectors of the constituent entity of the Russian Federation
}

\author{
T.Yu. Vasilyeva*, O.A. Romanova, S.Yu. Pavlova, and L.A. Savinova \\ I.N. Ulianov Chuvash State University, Cheboksary, Russia
}

\begin{abstract}
The features of modern taxation in the context of economic sectors are considered on the example of a specific region of Russia. The structure of tax revenues, gross regional product, as well as our own calculations of the actual tax burden in the context of economic activities of the Chuvash Republic are studied. It is revealed that in the studied region, such types of economic sectors as manufacturing, construction, and extraction of minerals bear a high tax burden, and in the republic as a whole, the tax burden is unevenly distributed across economic sectors due to the current structure of the region's economy. At the same time, the peculiarities of taxation of agriculture contributed to the fact that this industry provided only $0.4 \%$ of all received tax payments in Chuvashia. The agricultural sector bears a minimal tax burden. It is concluded that in current taxation conditions, organizations and entrepreneurs of the agricultural sector find it economically feasible to calculate and plan their tax burden.
\end{abstract}

\section{Introduction}

The purpose of the proposed study was to identify the taxation features of economic sectors - both in Russia as a whole, and on the example of such a constituent entity of the Volga Federal District as the Chuvash Republic.

In the scientific literature, the issues of fair taxation and optimal tax burden, in which the current level of taxation does not hinder the development of economic activity, are always widely discussed. An urgent issue today is the adoption of "such legislation that would create an appropriate business climate for business entities" [1, p. 194]. At the same time, as L.N. Lykova correctly notes, "the tax burden on various tax bases in the Russian Federation differs significantly, and there are also differences from European counterparts" [2, p. 76]. The authors also note that "the tax burden is highly differentiated for the entities" [3].

The studied constituent entity of the Russian Federation - the Chuvash Republic (Chuvashia) - is a geographically small but densely populated region of the Volga region with a predominantly rural territory, which has a favorable economic and geographical position and favorable initial opportunities for economic development in the form of transport infrastructure (these are waterways, pipeline transport, and a developed road system). Considering the level of the actual tax burden and tax potential of the regions of such a huge

*Corresponding author: tanya-7878@mail.ru 
country as Russia, we cannot but take into account their high territorial differentiation in terms of natural resources availability, geographical location, sectoral structure of the economy and socio-economic conditions, and, accordingly, in terms of their importance in the formation of the revenue part of the budget of Russia. Consider the current structure of the gross regional product (GRP) as a whole in the Russian Federation and in two regions of the Volga Region - the Chuvash Republic and the Republic of Tatarstan (Table 1 and Figure 1, compiled according to the Federal State Statistics Service of the Russian Federation). As can be seen from the data in Table 1, as well as Figure 1, in terms of the gross regional product, manufacturing industries prevail $(17.3 \%)$, followed by trade $(12.5 \%)$ and extraction of minerals (13, nine\%), in the Russian Federation as a whole. A completely different picture of the gross regional product (hereinafter - GRP) distribution is presented for such regions of Russia as the Chuvash Republic (subsidized region) and the Republic of Tatarstan (a donor region with a developed petrochemical complex). Extraction of minerals in the industry structure of GRP occupies $28.7 \%$ in Tatarstan and $0.1 \%$ in Chuvashia. The agricultural sector in the structure of the economy of Chuvashia occupies $8.2 \%$ (fourth place) against $5.5 \%$ in the Republic of Tatarstan.

Table 1. Industry structure of GRP in $2018-2019, \%$ [4, 5, 6].

\begin{tabular}{|c|c|c|c|c|c|c|}
\hline \multirow{2}{*}{ Type of economic activity } & \multicolumn{2}{|c|}{$\begin{array}{l}\text { the Russian } \\
\text { Federation }\end{array}$} & \multicolumn{2}{|c|}{$\begin{array}{l}\text { the Chuvash } \\
\text { Republic }\end{array}$} & \multicolumn{2}{|c|}{$\begin{array}{l}\text { the Republic } \\
\text { of Tatarstan }\end{array}$} \\
\hline & 2018 & 2019 & 2018 & 2019 & 2018 & 2019 \\
\hline $\begin{array}{l}\text { Financial and insurance } \\
\text { activities }\end{array}$ & 0.5 & 0.5 & 0.4 & 0.4 & 0.3 & 0.3 \\
\hline Provision of other services & 0.5 & 0.5 & 0.5 & 0.6 & 0.5 & 0.5 \\
\hline $\begin{array}{l}\text { Water supply; pollution control } \\
\text { and water disposal }\end{array}$ & 0.6 & 0.6 & 0.7 & 0.7 & 0.4 & 0.4 \\
\hline $\begin{array}{l}\text { Activities of hotels and public } \\
\text { catering enterprises }\end{array}$ & 1 & 1.0 & 1.5 & 1.4 & 0.9 & 0.9 \\
\hline $\begin{array}{l}\text { Activities in the field of culture, } \\
\text { sports, leisure activities }\end{array}$ & 0.9 & 1.0 & 1 & 0.9 & 1 & 1 \\
\hline Administrative activities & 2.2 & 2.3 & 0.9 & 0.9 & 1.3 & 1.5 \\
\hline $\begin{array}{l}\text { Provision of electricity, gas and } \\
\text { steam }\end{array}$ & 2.9 & 2.9 & 3.7 & 3.5 & 1.9 & 1.9 \\
\hline $\begin{array}{l}\text { Information and } \\
\text { communication activities }\end{array}$ & 2.8 & 3.0 & 2.6 & 2.7 & 1.9 & 2.1 \\
\hline Education & 2.9 & 3.0 & 4.2 & 4.3 & 2.4 & 2.6 \\
\hline $\begin{array}{l}\text { Health and social services } \\
\text { activities }\end{array}$ & 3.9 & 4.0 & 5.4 & 5.5 & 2.3 & 2.3 \\
\hline $\begin{array}{l}\text { Agriculture, forestry, hunting, } \\
\text { fishing and fish farming }\end{array}$ & 4 & 4.1 & 7.8 & 8.2 & 5.3 & 5.5 \\
\hline $\begin{array}{l}\text { Professional, scientific and } \\
\text { technical activities }\end{array}$ & 4.1 & 4.3 & 2.7 & 2.8 & 3.2 & 3.1 \\
\hline Construction. & 5.2 & 5.4 & 5.9 & 5.8 & 7.8 & 7.3 \\
\hline $\begin{array}{l}\text { Public administration and } \\
\text { military security provision }\end{array}$ & 5.5 & 5.6 & 6.5 & 6.3 & 3.3 & 3.4 \\
\hline Transportation and storage & 7.2 & 7.3 & 5.3 & 5 & 5.6 & 5.8 \\
\hline $\begin{array}{l}\text { Activities related to real estate } \\
\text { transactions }\end{array}$ & 10 & 10.0 & 12.2 & 12.5 & 7.5 & 8 \\
\hline Extraction of minerals & 13.9 & 13.5 & 0.1 & 0.1 & 28.7 & 28.7 \\
\hline $\begin{array}{l}\text { Wholesale and retail trade; } \\
\text { repair of motor vehicles }\end{array}$ & 14.6 & 14.2 & 12.7 & 12.5 & 10.8 & 10.4 \\
\hline Manufacturing industries & 17.3 & 16.8 & 25.9 & 25.9 & 14.9 & 14.3 \\
\hline Total & 100.0 & 100.0 & 100.0 & 100.0 & 100.0 & 100.0 \\
\hline
\end{tabular}




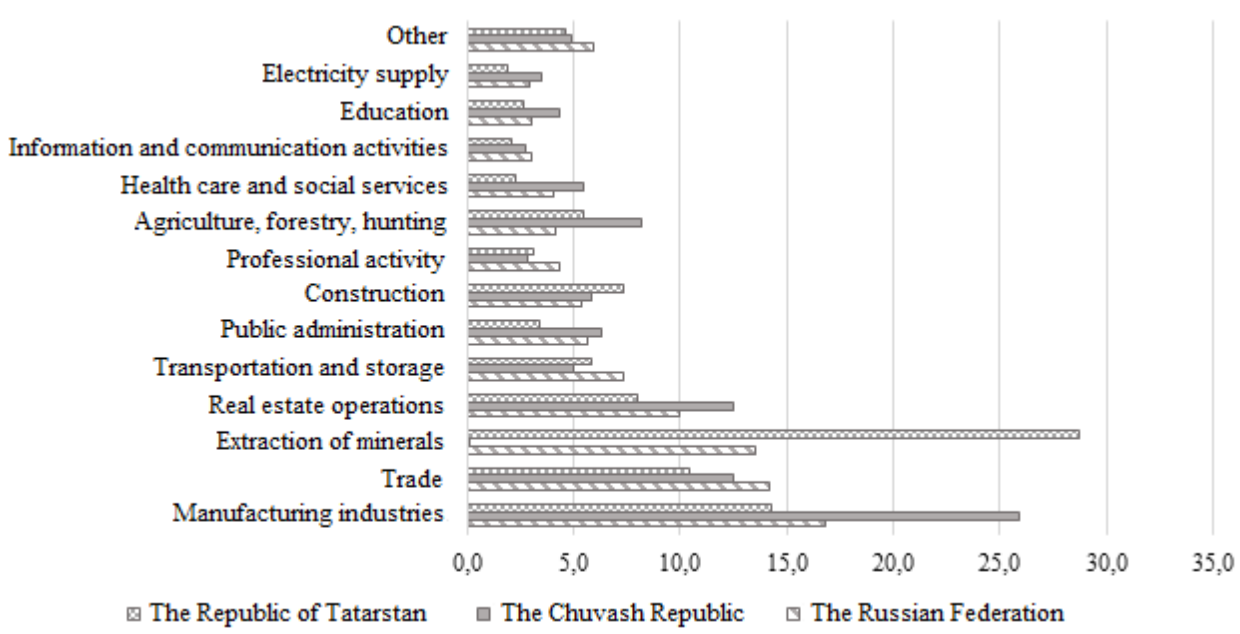

Fig. 1. Structure of the gross regional product by industry in 2018-2019, \%

The sectoral structural analysis of GRP production for 2019, shown in Table 1 and Figure 1, shows that the main economic sector for the Republic of Chuvashia is "manufacturing", the share of production was $25.9 \%$, and then, in descending order, there are retail and wholesale trade $(12.5 \%)$, real estate operations (12.5\%), agriculture and fishing $(8.2 \%)$, and extraction of minerals is in last place $(0.1 \%)$. So, in terms of the relative share of the gross regional product in the region under study, the first place is occupied by manufacturing industries, the second - trade, and the third - agriculture.

Thus, the shown initial differences in the structure of the economy of the regions inevitably entail an uneven distribution of tax payments in the context of the entity of the Russian Federation. Table 2 shows the structure of tax payments on the example of the same above-mentioned regions and for Russia as a whole.

Table 2. Structure of tax payments in 2019, \% [7]

\begin{tabular}{|l|c|c|c|}
\hline \multicolumn{1}{|c|}{ Tax } & Russia (as a whole) & Tatarstan & Chuvashia \\
\hline Extraction tax & 27.1 & 46.1 & 0.1 \\
\hline Income tax & 20.2 & 17.6 & 18.0 \\
\hline Personal income tax & 17.6 & 10.1 & 26.5 \\
\hline Value added tax & 19.9 & 16.0 & 33.2 \\
\hline Property taxes & 6.0 & 4.9 & 9.0 \\
\hline Excise taxes & 5.7 & 3.6 & 6.4 \\
\hline Other taxes & 3.5 & 1.7 & 6.8 \\
\hline Total & 100.0 & $100.0 \%$ & 100.0 \\
\hline
\end{tabular}

From the data in Table 2, it can be seen that in Russia, the structure of taxes paid is dominated by the extraction tax $(27.1 \%)$. In the Republic of Tatarstan, which is rich in oil revenues, respectively, there is high relative share of the extraction tax $(46.1 \%)$, and it is minimal in Chuvashia.

\section{Methods}

The article uses such research methods as the study and generalization of scientific literature, logical and comparative methods of study, as well as graphic representation, study and 
analysis of statistical data of the Federal Tax Service of Russia, the Federal State Statistics Service of Russia.

The analyzed region of Russia - the Chuvash Republic - "is traditionally a subsidized region of Russia" [8, p. 155]. The structure of taxes paid in the Chuvash Republic for 2019 is shown in the following figure (Figure 2).

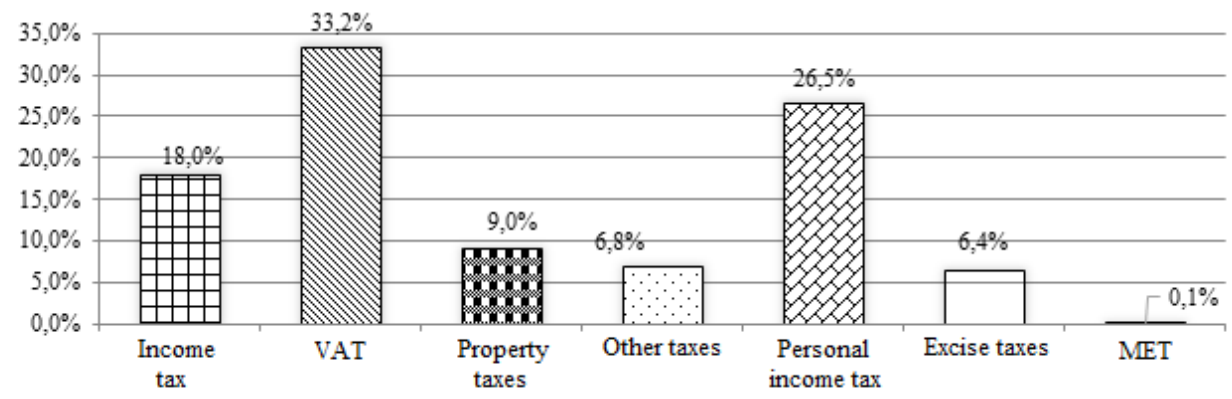

Fig. 2. Structure of taxes paid in the Chuvash Republic for 2019.

In the entity under consideration, there is almost no resource and raw material base, so there is no taxable base for the extraction tax (ET), which is the leader in the Russian Federation as a whole in terms of the structure of taxes received $(27.1 \%)$ and is only $0.1 \%$ in Chuvashia. Table 3 calculates the level of the actual tax burden in the sectoral context in the Chuvash Republic by the ratio of mobilized tax payments to GRP. For the purpose of the analysis, the criterion of the tax burden on the region economy was chosen as "an indicator of the assessment of taxation impact on the socio-economic development of the region, taking into account its sectoral structure and its regional tax policy" [9, p.365].

Table 3. Calculation of tax burden in the Chuvash Republic in 2019

\begin{tabular}{|l|c|c|c|}
\hline \multicolumn{1}{|c|}{ Economic sector } & $\begin{array}{c}\text { Taxes, } \\
\text { million rubles }\end{array}$ & $\begin{array}{c}\text { GRP, } \\
\text { million rubles }\end{array}$ & $\begin{array}{c}\text { Tax burden, } \\
\%\end{array}$ \\
\hline Manufacturing industries & 24943.2 & 87999.5 & 28.3 \\
\hline $\begin{array}{l}\text { Wholesale and retail trade; repair of motor } \\
\text { vehicles and motorcycles }\end{array}$ & 6746.8 & 42470.8 & 15.9 \\
\hline Construction. & 3901.5 & 19706.5 & 19.8 \\
\hline Professional, scientific and technical activities & 2080.9 & 9513.5 & 21.9 \\
\hline Transportation and storage & 1889.8 & 16988.3 & 11.1 \\
\hline Financial and insurance activities & 1875.8 & 1359.1 & 138.0 \\
\hline $\begin{array}{l}\text { Provision of electricity, gas and steam; air } \\
\text { conditioning }\end{array}$ & 1743.8 & 11891.8 & 14.7 \\
\hline $\begin{array}{l}\text { Public administration and military security } \\
\text { provision; social security }\end{array}$ & 1734.0 & 21405.3 & 8.1 \\
\hline Health and social services activities & 1707.2 & 18687.2 & 9.1 \\
\hline Education & 1706.3 & 14610.0 & 11.7 \\
\hline Activities related to real estate transactions & 1295.8 & 42470.8 & 3.1 \\
\hline Information and communication activities & 1029.9 & 9173.7 & 11.2 \\
\hline $\begin{array}{l}\text { Water supply; water disposal, organization of } \\
\text { waste collection and disposal, pollution } \\
\text { elimination activities }\end{array}$ & 839.6 & 2378.4 & 35.3 \\
\hline $\begin{array}{l}\text { Administrative activity and related additional } \\
\text { services }\end{array}$ & 453.2 & 3057.9 & 14.8 \\
\hline $\begin{array}{l}\text { Activities of hotels and public catering } \\
\text { enterprises }\end{array}$ & 396.1 & 4756.7 & 8.3 \\
\hline
\end{tabular}




\begin{tabular}{|l|c|c|c|}
\hline $\begin{array}{l}\text { Activities in the field of culture, sports, leisure } \\
\text { and entertainment }\end{array}$ & 361.2 & 3057.9 & 11.8 \\
\hline $\begin{array}{l}\text { Agriculture, forestry, hunting, fishing and fish } \\
\text { farming }\end{array}$ & 216.2 & 27860.9 & 0.8 \\
\hline Provision of other services & 152.6 & 2038.6 & 7.5 \\
\hline Extraction of minerals & 87.5 & 339.8 & 25.7 \\
\hline
\end{tabular}

As can be seen from Figure 3, a significant tax burden is borne by such activities as manufacturing, construction, and extraction of minerals. So, such activities as manufacturing and trade are leading both in the structure of GRP and in the structure of tax payments. At the same time, there is a clear discrepancy in the structure of GRP and the level of tax burden -agricultural activities occupy the fourth place in terms of the share of GRP and the last place in terms of tax burden. The agricultural sector provided only $0.4 \%$ of the mobilized tax revenues in Chuvashia.

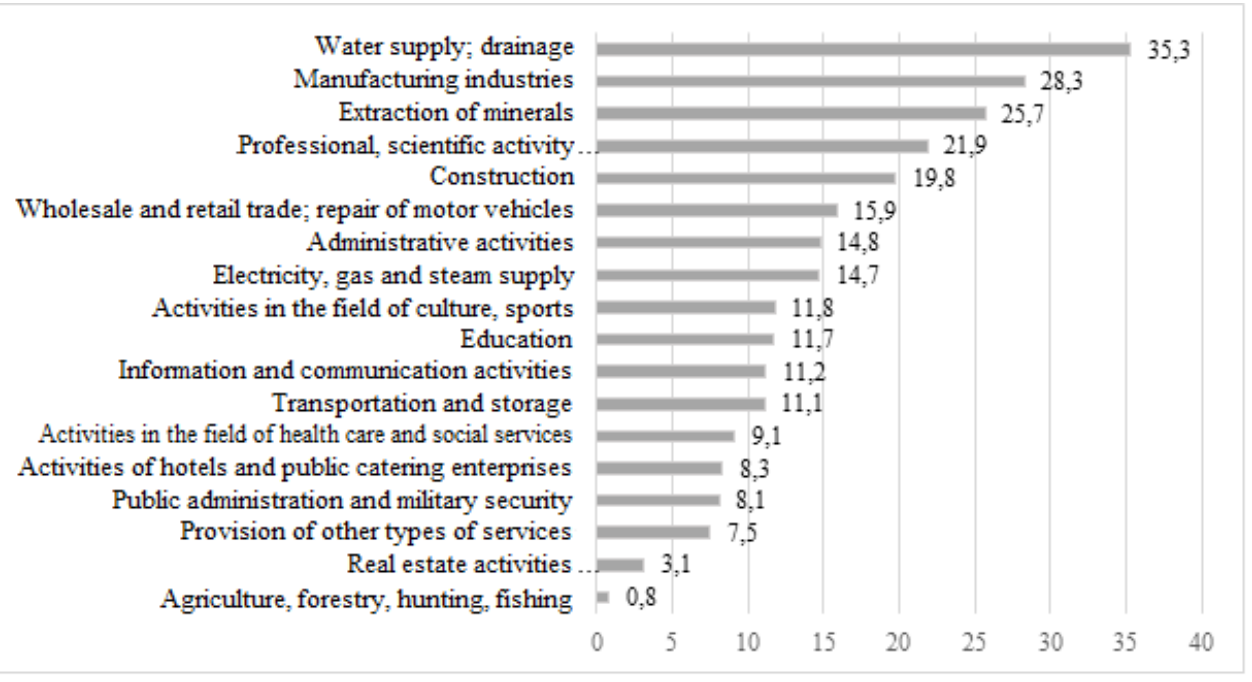

Fig. 3. Actual tax burden for economic activity of the Chuvash Republic in $2019, \%$

This is due to the fact that, according to the Tax Code effective in Russia, organizations and individual entrepreneurs can apply such tax systems (regimes) as [10]:

- general (regular) tax system;

- SAT, that is, a special tax regime in the form of a single agricultural tax;

- STS, that is, a special tax regime in the form of a simplified tax system;

- PST, that is, the patent system of taxation (can be applied exclusively by individual entrepreneurs).

As shown by our in-depth additional analysis of tax statistical reporting forms, in Chuvashia, simplified taxation systems are mainly used by trade entities - their share was $34 \%$ of the total amount of taxes received under special tax regimes. The construction industry is in second place $(11.97 \%)$, and the manufacturing industry is in third place $(11.3 \%)$.

\section{Results}

We will analyze the taxation of such an important activity for the Chuvash Republic as agricultural activity. The structure of mobilized tax payments for this industry for 2019 in the Chuvash Republic is given in Table 4, which shows that with a relatively high share of GRP 
in agriculture, this industry bears a low tax burden, which is primarily due to state support for the industry, high costs and low profitability.

Table 4. Structure of mobilized tax payments

for agricultural activity in the Chuvash Republic for 2019

\begin{tabular}{|l|c|c|}
\hline \multicolumn{1}{|c|}{ Tax } & $\begin{array}{c}\text { Amount, thousand } \\
\text { rubles }\end{array}$ & Relative share, \% \\
\hline Value added tax & -379766 & $\mathrm{x}$ \\
\hline $\begin{array}{l}\text { Taxes and fees for the use of natural } \\
\text { resources }\end{array}$ & 1686 & 0.3 \\
\hline Transport tax & 9942 & 1.7 \\
\hline Other taxes & 15293 & 2.7 \\
\hline Corporate income tax & 56032 & 9.9 \\
\hline Corporate property tax & 63822 & 11.2 \\
\hline Taxes under special tax regimes & 73280 & 12.9 \\
\hline Personal income tax & 348286 & 61.3 \\
\hline Total & 188575 & 100.0 \\
\hline
\end{tabular}

The data in Table 4 show that the relative share of received tax payments in the agricultural sector from the applied special regimes is low - it amounted to only $12.9 \%$ of all taxes paid in this industry, excluding VAT. At the same time, the amount of tax payments received from the single agricultural tax (hereinafter referred to as the SAT) for 2019 amounted to 34,643 thousand rubles, which is about half of all tax revenues under special regimes. It turns out that in the Chuvash Republic, agricultural activities account for $8.3 \%$ of GRP and only $0.4 \%$ of tax revenues. The value of the tax burden in the agricultural sector is minimal (Figure 3), which is explained by the negative amount of VAT (Table 4), as well as a significant share of costs in this activity. The value added tax (VAT) is negative, which is explained by the following. The tax rate of accrued VAT on the sale of agricultural products is $10 \%$, and the rate of incoming VAT on purchases is $20 \%$, which means that the value of VAT on sales is less than VAT on purchases, as a result of this tax, there is a tax debt of the budget to the agricultural organization (entrepreneur).

There are other methods of tax incentives for agriculture in Russia with the help of the provided benefits. For example, if an organization applies a conventional tax system, the profit from the sale of agricultural products that have undergone primary processing is not subject to income tax. In case when a special regime is applied in the form of SAT (single agricultural tax), the established tax rate is low and amounts to $6 \%$ of the profit received, despite the fact that in this industry the share of costs is significant. More recently, the use of SAT was preferred to agricultural producers, but from January 1, 2019, VAT on the SAT application is subject to mandatory payment, except in cases where the amount of income, for example, for 2019 does not exceed 90 million rubles (the legally established limit is reduced every year) and the taxpayer applied to the tax service.

In our opinion, the new rule on the application of a single agricultural tax with VAT is beneficial for agricultural producers, as it opens up new markets for them that were previously inaccessible - we are talking about counterparties - large organizations (buyers and customers) that use a common tax regime and it is important for them to have input VAT on purchases for subsequent reimbursement from the budget. In case if the buyers are mainly individuals, as well as legal entities that apply special tax regimes and are therefore exempt from VAT, we recommend to analyze the tax burden and compare the resulting amount of taxes payable when applying two special tax regimes - the STS and the SAT. Note that under the simplified tax system, the basic rate is $15 \%$ (from the amount of income reduced by the amount of expenses), but VAT is not paid. It is also worth considering that when applying both the SAT and the general taxation system, the total amount of VAT payable to the budget by organizations and entrepreneurs of agriculture is usually negative, that is, it forms a tax 
deduction due to different VAT rates on purchases of goods and on sales. At the same time, the input VAT is not taken into account in the expenses under SAT, as it was before 2019.

\section{Conclusion}

Thus, the features of sectoral taxation are studied on the example of such a subsidized entity of the Russian Federation as the Chuvash Republic, which was the purpose of the study. The dynamics and structure of tax revenues and gross regional product in the context of economic activities are considered and compared. The analysis showed that in Chuvashia, manufacturing is the leader in terms of the share of GRP, with trade and agriculture being the next sectors. At the same time, the tax burden is extremely unevenly distributed across economic activities. For example, the lowest tax burden is borne by agriculture, and the highest tax burden in the Chuvash Republic is borne by manufacturing industries due to the current structure of the region's economy, high equipment of fixed assets, a significant length of the production cycle, as well as a high level of tax control by tax authorities (especially large taxpayers). To calculate the tax burden, the main indicators were the actual tax revenues mobilized on the territory of the Chuvash Republic and the gross regional product (GRP). GRP is used as an indicator that "at the regional level aggregates the tax base for such taxes as personal income tax, excise taxes, value added tax, corporate profit tax" [11, p.183], the share of which in the structure of taxes paid in the Chuvash Republic in 2019 was $84 \%$. The analysis of the taxation practice at the regional level in the sectoral context is of interest from the point of view of assessing the prospects for potential tax revenues.

\section{References}

1. Yu.B. Ivanov, Yu.M. Malyshko, Journal of Tax Reform, 1 (2-3), 194-208 (2015)

2. L.N. Lykova, Journal of Tax Reform, 1 (1), 76-89 (2015) https://doi.org/10.15826 /jtr.2015.1.1.005

3. N. Zotikov, O. Arlanova, M. Lvova, Regulatory role of taxes in formation of incomes of various levels budgets in the russian federation, IOP Conference Series: Earth and Environmental Science. International AgroScience Conference, AgroScience 2019, 012040 (2020)

4. Data from the website of the Federal State Statistics Service, URL: http://www.gks.ru.

5. Official publications of the Chuvashstat, Territorial body of the Federal State Statistics Service for the Chuvash Republic, URL:https://chuvash.gks.ru/official_publications

6. Chuvashia in numbers, Sh.stat.coll. (Chuvashstat, Cheboksary, 210 (2020)

7. Data on statistical tax reporting forms, Federal Tax Service: of. Website, URL: https://www.nalog.ru/rn21/related_activities/statistics_and_analytics/forms

8. P.A. Vasiliev, Analysis of the tax system activity at the regional level (on the example of the Chuvash Republic), Economics and Ecology: trends, problems, solutions: materials of the International Scientific and Practical Conference, Cheboksary, Chuvash University Publishing House, 155-157 (2017)

9. P.A. Vasiliev, Development of the methodology for assessing the impact of the tax system on the economy of the region, Problems and prospects for the development of the socio-economic potential of the Russian regions: materials of the V All-Russian Electronic Scientific and Practical conference, Cheboksary, Chuvash University Publishing House, 363-366 (2016)

10. Tax Code of the Russian Federation. P. II dd 05.08.2000 No. 117-FZ (with amendments 
and additions), Access from the reference legal system "Consultant Plus"

11. T.Yu. Vasilieva, Development of tax potential as a condition for improving regional economic policy. Dissertation for the degree of Candidate of Economic Sciences, Chuvash State University n.a. I.N. Ulyanov, Cheboksary, 216 (2008) URL: https://elibrary.ru/item.asp?id=16182677 